\title{
Bioactivity profile of three types of seaweed as an antioxidant, $U V$-protection as sunscreen and their correlation activity
}

\author{
1,2,*Sami F.J., ${ }^{1}$ Soekamto N.H., ${ }^{1}$ Firdaus and ${ }^{3}$ Latip J. \\ ${ }^{I}$ Department of Chemistry, Faculty of Mathematics and Natural Sciences, Universitas Hasanuddin, \\ Makassar, Indonesia \\ ${ }^{2}$ Department of Pharmaceutical Chemistry, Sekolah Tinggi Ilmu Farmasi Makassar, Indonesia \\ ${ }^{3}$ School of Chemical Sciences and Food Technology, University Kebangsaan Malaysia
}

Article history:

Received: 26 July 2020

Received in revised form: 30

August 2020

Accepted: 30 October 2020

Available Online: 13

February 2021

\section{Keywords:}

Seaweed,

Antioxidant,

UV-protection,

E. cottoni,

S. polycystum,

C. racemosa

\section{DOI:}

https://doi.org/10.26656/fr.2017.5(1).389

\begin{abstract}
Seaweed is one of the marine algae that have antioxidant sources because it contains bioactive compounds such as carotenoids, phenol compounds and their derivatives, polysaccharide sulfate, and vitamins. Algae consist of three major groups namely brown algae (phaeophyta), red algae (rhodophyta), and green algae (chlorophyta). The purpose of this study was to determine the bioactivity profile of seaweed extract Eucheuma cottoni, Sargassum polycystum and Caulerpa racemosa so that it could be developed as a cosmetic raw material. The three types of seaweed were extracted by maceration and bioactivity testing was carried out as an antioxidant using the ABTS radical reduction method and bioactivity testing as UV-protection with the parameters of the percentage transmission of erythema, pigmentation and Sun Protective Factor (SPF). The results showed that $C$. racemosa extract provided a very strong antioxidant activity and was able to protect the skin from UV exposure with an SPF value that was categorized as ultra-protection. Antioxidant activity of the three types of seaweed is positively correlated to the protective effect based on the SPF value.
\end{abstract}

\section{Introduction}

Seaweed is an aquatic organism that is classified into macro-algae class and its existence is very abundant as well as one of the valuable marine biological natural resources (Yanuarti et al., 2017; Tanna and Mishra, 2019). Seaweed consists of three major groups based on the color pigments namely brown algae (phaeophyta), red algae (Rhodophyta), and green algae (Chlorophyta) (Yende et al., 2014; Yap et al., 2019). Seaweed can be counted as a source of bioactive compounds because of their ability to produce secondary metabolites that vary greatly with very broad biological activity (Subrathraa and Poonguzhali, 2013). In general, seaweed contains fiber, protein, fat, vitamins and minerals, besides that there are polysaccharides such as carrageenan and alginate which are components that are often exploited (Alam Bhuiyan and Qureshi, 2016; Nofiani et al., 2018; Sinurat and Fadjriah, 2019; Tanna and Mishra, 2019). Several countries in Asia and Europe using seaweed as fertilizer for agriculture, as well as thickening and gelforming agents for industrial applications such as food, meat products, milk product in food industries and some additional ingredients in cosmetics industries (Kraan,
2012; Kılınç et al., 2013; Tanna and Mishra, 2019). In addition, there are many types of secondary metabolites found in seaweed that are currently very widely used in the development of new drugs and cosmetics. Seaweed is one source of antioxidants because it contains bioactive compounds such as carotenoids, steroids, terpenoids, phenol compounds and their derivatives, flavonoids, coumarin as well as vitamins (MacArtain et al., 2008).

Several studies have reported that E. cottoni red seaweed has pharmacological activity as an anti-cancer (Kania et al., 2013; Arsianti et al., 2018), antioxidant (Matanjun et al., 2008; Wresdiyati et al., 2008; Muawanah et al., 2016) anti-inflammatory (Sudirman et al., 2018) and sunscreen (Pakki et al., 2018). Green seaweed such as $C$. racemosa has biological activities such as antioxidants (Kumar et al., 2011; Nofiani et al., 2018; Yap et al., 2019), antibacterial (Chan et al., 2018), and anti-inflammatory (Bitencourt et al., 2015). In additions brown seaweed such as $S$. polycystum has pharmacological effect as antioxidant (Chandini et al, 2008; Yende et al., 2014; Sami et al., 2019), anti-tumor (Yende et al., 2014), analgesic and anti-inflammation (Hong et al., 2011; Yende et al., 2014), neuroprotective 
(Hong et al., 2011; Yende et al., 2014), sunscreen (Pakki et al., 2018) and anti-viral activity (Yende et al., 2014).

Nowadays, seaweed is still being developed in various industries, especially in the cosmetics industry. The phenolic content and its derivatives as well as the flavonoid content found in E. cottoni, C. racemosa, and $S$. polycystum seaweed species so that they can be developed as cosmeceutical antioxidants and skin protection from UV exposure. In our study, a study will be conducted on the effect of antioxidants on skin protection from UV rays so that natural ingredients derived from marine algae have contributed as raw materials for the development of safe cosmetics.

\section{Materials and methods}

\subsection{Materials}

The material used such as reagents were analytical grade Ethanol, Aquabidestillata, 2,2'-Azino-bis (3ethylbenzothiazoline-6-sulfonic acid) diammonium salt (ABTS), Potassium Persulfate $\left(\mathrm{K}_{2} \mathrm{~S}_{2} \mathrm{O}_{8}\right)$, and Samples of red seaweed $E$. cottoni, green seaweed $C$. racemosa and brown seaweed $S$. polycystum were obtained in Punaga Village, Mangarabombang District, Takalar Regency, South Sulawesi.

\subsection{Sample preparation}

Samples of red seaweed (E. cottoni), brown seaweed (S. polycystum) and green seaweed (C. racemosa) were sorted and fresh seaweed was washed using running water to remove dirt, moss, mud and sand. Furthermore, chopping was done to facilitate the drying process carried out for 3 days not exposed to direct sunlight. The samples were then washed again using fresh water to remove the salt content of seaweed, then dried again 5-6 days not exposed to direct sunlight (Suryaningrum et al., 2006).

\subsection{Extraction process}

Extraction was done by maceration process where each dried seaweed powder was put into a maceration vessel and added with $96 \%$ ethanol solvent, then allowed to stand for $3 \times 24$ hrs occasionally stirring, and then filtered. Each sample was re-macerated for up to $48 \mathrm{hrs}$ using the same solvent. Each filtrate was taken then evaporated with a rotary evaporator to obtained crude extract of E. cottoni, C. racemosa and S. polycystum.

\subsection{Phytochemical screening}

Profiles of the secondary metabolites of flavonoids, tannins, steroids, terpenoids, saponins and alkaloids in all three types of seaweed were determined based on the colorimetric method using chemical reagents (Harborne, 1998).

\subsection{Antioxidant activity}

Antioxidant activity of three types of seaweed was carried out by radical scavenging colorimetric method. ABTS radical solution was prepared by mixing ABTS solution $2.76 \mathrm{mM}(7.1015 \mathrm{mg}$ ABTS in $5 \mathrm{~mL}$ aqubidestillata) with potassium persulfate $2.58 \mathrm{mM}$ (3.5 $\mathrm{mg} \mathrm{K} \mathrm{K}_{2} \mathrm{~S}_{8}$ in $5 \mathrm{~mL}$ aquabidestillata). Each solution was mixed and incubated for $12 \mathrm{hrs}$ in a dark room at room temperature. After the incubation period the volume was sufficient to $25 \mathrm{~mL}$ with ethanol analytical grade. Each sample was made a concentration series by dropping a certain amount of volume and the mixture was added with ABTS solution of $1 \mathrm{~mL}$. The volume was adjusted to $5 \mathrm{~mL}$ and incubated in a dark room at room temperature for 30 mins. The mixture was measured for absorption on a spectrophotometer at a wavelength of $750 \mathrm{~nm}$. In this study, ethanol was used as a blank and quercetin as a positive control. The percentage of ABTS radical inhibition by the presence of a sample can be calculated using the following equation:

$$
\text { Inhibition }(\%)=\frac{\text { Abs blank }- \text { Abs sample }}{\text { Abs blank }} \times 100 \%
$$

\subsection{Sunscreen assessment}

Testing the sunscreen activity of three types of seaweed is done by looking at the profile values of percentage of erythema transmission, pigmentation transmission and SPF (Eff et al., 2018; Pakki et al., 2018)

\subsubsection{Transmission of erythema (\%Te) and pigmentation (\%Tp)}

Each extract solution was made into a series of concentrations (1-1000 $\mu \mathrm{g} / \mathrm{mL})$ and then its transmission $(\% \mathrm{~T})$ was measured using a UV spectrophotometer at wavelengths that could cause erythema and pigmentation $(292.5 \mathrm{~nm}-372.5 \mathrm{~nm})$ with $5 \mathrm{~nm}$ interval. Based on the transmission value $(\% \mathrm{~T})$ obtained the percentage of transmission erythema and pigmentation (\% $\mathrm{Te}$ and $\% \mathrm{Tp})$ were calculated using the following formula:

$$
\% T e=\frac{\text { Eerythema transmission }(\mathrm{T} \times \mathrm{Fe})}{\Sigma \text { flux erythema }(\mathrm{Fe})}
$$

And

$$
\% T p=\frac{\text { Epigmentation transmission }(T \times F p)}{\Sigma \text { flux pigmentation }(F p)}
$$

Where $\mathrm{T}=$ Transmission in certain wavelength and $\mathrm{Fe} / \mathrm{Fp}=$ Flux erythema/Flux pigmentation value based on Table 1. 
Table 1. Flux erythema/Flux pigmentation value on wavelength number

\begin{tabular}{ccc}
\hline Wavelength $(\mathrm{nm})$ & Flux erythema (Fe) & Flux pigmentation $(\mathrm{Fp})$ \\
\hline 292,5 & 11,390 & - \\
297,5 & 65,100 & - \\
302.5 & 100,000 & - \\
307,5 & 35,770 & - \\
312,5 & 0,9734 & - \\
317,5 & 0,5670 & - \\
322,5 & 337,50 & 10,790 \\
327,5 & 0,2890 & 10,200 \\
332,5 & 0,1290 & 0,9360 \\
337,5 & 0,0456 & 0,7980 \\
342,5 & - & 0,6690 \\
347,5 & - & 0,5700 \\
352,5 & - & 0,4880 \\
357,5 & - & 0,4560 \\
362,5 & - & 0,3560 \\
367,5 & - & 0,3100 \\
372,5 & - & 0,2600 \\
\hline$\sum$ & 236,850 & 69,420 \\
\hline
\end{tabular}

\subsubsection{Sun protective factor (SPF) assessment}

Each sample solution was made in series of concentrations (1-1000 $\mu \mathrm{g} / \mathrm{mL})$ and subsequent absorption measurements were made using a UV spectrophotometer at wavelengths of 292.5-372.5 with a scale change distance every $5 \mathrm{~nm}$ once observed. The SPF value is calculated using the formula:

$$
\begin{aligned}
& \text { Area under Curve (AUC) }=\frac{A a+A b}{2} \times d P_{a-b} \\
& \log S P F=\frac{A U C}{\lambda n-\lambda 1} \times D F
\end{aligned}
$$

here $A_{a}=$ Absorbance in wavelength $a \mathrm{~nm}, A_{b}=$ Absorbance in wavelength $\mathrm{b} \mathrm{nm}, \mathrm{dP}_{\mathrm{a}-\mathrm{b}}=$ Difference in wavelengths $\mathrm{a}$ and $\mathrm{b}, \lambda \mathrm{n}=$ The largest wavelength (with $\mathrm{A} \geq 0.05), \lambda_{1}=$ Smallest wavelength $(290 \mathrm{~nm}), \mathrm{DF}=$ Dilution factor ( $\mathrm{FP}=1$ for extract)

\subsection{Data analysis}

The data of antioxidant and sunscreen assessment were analyzed by Microsoft Excel program with expressed as mean \pm standard deviation (SD).

\section{Results and discussion}

\subsection{Extraction}

Seaweed samples in the form of E. cottoni, $C$. racemosa, $S$. polycystum were extracted by maceration which aims to attract the chemical components contained in each sample. Based on the results of maceration using $96 \%$ ethanol was obtained percent of yield contained in Table 2. One of the successful process to pull out of chemical components into the sample is the selection of solvents. Table 3 shows that the $S$. polycystum sample gave a large percent yield than the others followed by $C$. racemosa and E. cottoni.

\subsection{Chemical compounds}

Each extract that has been obtained is then identified as the components of the compound by using specific chemical reagents. Table 2 shows that the chemical compounds into the three types of seaweeds. From the

Table 2. Percentage of yield samples extract

\begin{tabular}{cc}
\hline Samples Extract & Yield (\%) \\
\hline E. cottoni & 11.6 \\
S. polycystum & 29.7 \\
C. racemosa & 24.8 \\
\hline
\end{tabular}

Table 3. Profile of chemical compounds in three types of

\begin{tabular}{|c|c|c|c|c|c|c|}
\hline Sample & $\begin{array}{l}\frac{\infty}{0} \\
\frac{0}{0} \\
\frac{0}{\infty}\end{array}$ & 苞. & 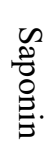 & 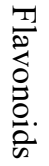 & $\begin{array}{l}\frac{D}{\mathbb{R}_{0}} \\
\frac{0}{0} \\
\frac{0}{0}\end{array}$ & $\begin{array}{l}-1 \\
0 \\
0 \\
0 \\
0 \\
0\end{array}$ \\
\hline E. cottoni & + & - & + & + & + & - \\
\hline S. polycystum & - & - & - & + & + & + \\
\hline C. racemosa & + & + & - & + & + & - \\
\hline
\end{tabular}
seaweeds

$+=$ positive contain chemical compounds, $-=$ negative contain chemical compounds

results of phytochemical screening, it can be seen that three types of seaweed extract from Indonesian marine contains several secondary metabolite components such as alkaloids, flavonoids, saponins, steroids, tannin and terpenoids. However, in this study, different results were obtained from previous studies of E. cottoni extract containing flavonoids and terpenoids group (Suryaningrum et al., 2006), S. polycystum extract contained flavonoid, saponins, steroids and triterpenoids compounds (Cahyaningrum et al., 2016), and $C$. racemosa extract containing phenol compounds, and tannins (Adhita Putera, 2015). This may be influenced by several factors such as the influence of the location of growth, improper harvest time and changing weather climate (Adhita Putera, 2015).

\subsection{Antioxidant activity by ABTS radical scavenger}

Antioxidant activity assessment by radical ABTS scavenging method is used to determining the antioxidant activity obtained by the oxidation of potassium persulfate with ABTS diazonium salt. Radical ABTS provides maximum absorption at a wavelength of $750 \mathrm{~nm}$ (Re et al., 1999). The presence of antioxidant compounds from the sample is marked by the loss of blue color in the ABTS radical reagent (Mistriyani et al., 2018). Each serial concentration of three types of seaweed was then measured on a UV-Vis spectrophotometer with a quercetin as positive control. The amount of antioxidant activity is indicated by the $\mathrm{IC}_{50}$ value, which is the concentration of the sample 
solution needed to inhibit $50 \%$ of ABTS free radicals. Figure 1 shows the $\mathrm{IC}_{50}$ value of three types of seaweed indicating that the lower of the $\mathrm{IC}_{50}$ value, the stronger its antioxidant activity.

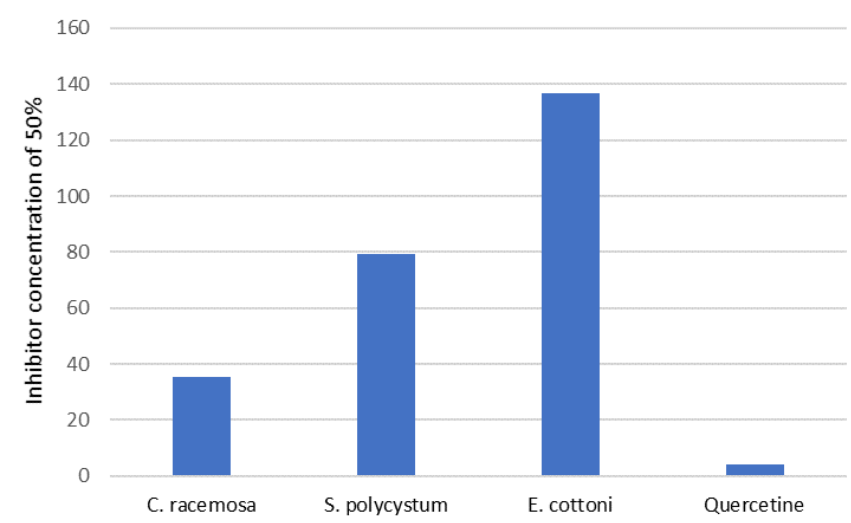

Figure 1. Inhibitor Concentration of 50\% value of three types of seaweed. The data was express as mean \pm SD with triplicate $(\mathrm{n}=3)$

The results of the antioxidant activity assessment of the three types of seaweed showed that $C$. racemosa extract provided a very strong antioxidant activity with an $\mathrm{IC}_{50}$ value of $35.55 \mu \mathrm{g} / \mathrm{mL}$ followed by $S$. polycystum and $E$. cottoni with $\mathrm{IC}_{50}$ values respectively of $79.29 \mu \mathrm{g} /$ $\mathrm{mL}$ (strong activity) and $136.7 \mu \mathrm{g} / \mathrm{mL}$ (moderate activity). The very strong antioxidant activity of $C$. racemosa is supported by the presence of phenolic derivate compounds such as tannin and flavonoid which contribute to reducing free radicals by donating their protons (-H) (Apak et al., 2007; Nur et al., 2019).

\subsection{Sunscreen assessment}

Sunscreen activity assessment of the three types of seaweed was carried out based on three main parameters in vitro, namely determining the percentage of erythema transmission, percentage of pigmentation transmission and determining the SPF value (K1lınç et al., 2013; Donglikar and Deore, 2016; Eff et al., 2018; Pakki et al., 2018). In this study, the percentage of erythema and pigmentation transmission were evaluated by spectrophotometer analysis with serial concentration of seaweed samples (0.02-0.1\%), flux erythema and pigmentation value on wavelength number can be seen in Table 3. Figure 2 shows the graph percentage of erythema transmission in difference concentration. The graph indicated that the higher the concentration of the sample indicates the lower percentage of erythema transmission. This shows that the samples have the ability to absorb UV rays so as to reduce the amount of exposure that can cause erythema on the skin. Similar results were also found in the percentage profile of pigmentation transmission (Figure 3). This also shows that seaweed samples have the ability to absorb UV radiation so that the reduced amount of excessive light exposure can cause pigmentation on the skin (Eff et al.,
2018). The results of these assessments indicate that $C$. racemosa ethanol extract provides a decrease in the amount of UV radiation exposure so as to allow the adverse effects of erythema and pigmentation to be reduced.

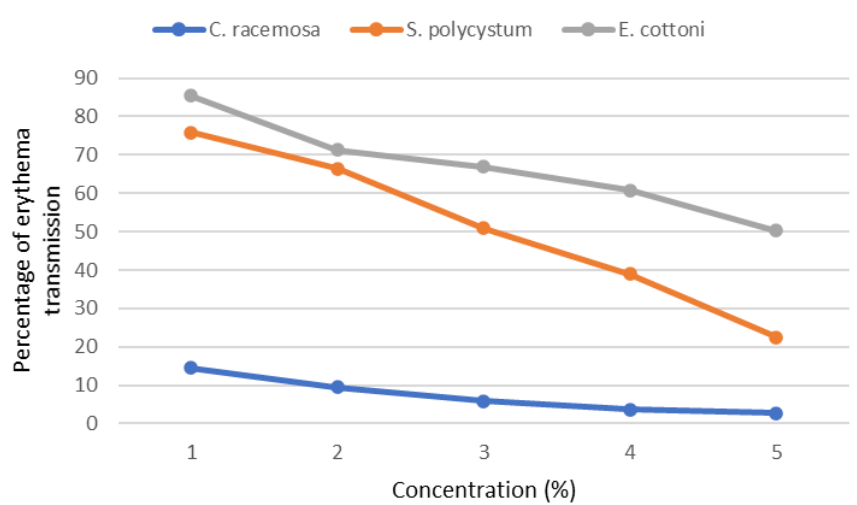

Figure 2. Profile the percentage of erythema transmission from three types of seaweed

The next sunscreens assessment parameter from three types of seaweed were evaluated is sun protective factor (SPF). SPF value is a measure of the level of protection against UV-B rays $(290-230 \mathrm{~nm})$ which is the most dangerous group of rays that can cause damage more quickly and easily than UV-A rays (230-400 nm). SPF assessment was performed on each extract of seaweed with the highest concentration of $0.1 \%$. The choice of concentration is based on the results of optimization that have been done and based on the concentration that gives an effect on the percentage parameters of erythema transmission and pigmentation. The results of the evaluation of the SPF value can be seen in Table 4.

Table 4. SPF value of three types of seaweed with the concentration of extract $0.1 \%$

\begin{tabular}{ccc}
\hline Samples Extract & SPF Value & Categories* \\
\hline E. cottoni & $1.02 \pm 0.71$ & Low protection \\
S. polycystum & $2.41 \pm 0.22$ & Minimal protection \\
C. racemosa & $22.59 \pm 0.98$ & Ultra protection \\
\hline
\end{tabular}

*Source: Balsam and Sagarin (1972)

Based on Table 4 indicated that the seaweed $C$. racemosa type gave activity as UV protection with category ultra-protection followed by $S$. polycystum with category minimal protection and $E$. cottoni with category was low protection. Seaweed has activity as UV protection because it is thought that there are chemical compounds capable of absorbing was strong UV rays between UVA and UVB. In this study, the results obtained that $C$. racemosa seaweed provides the best activity compared to other types of seaweeds. 


\subsection{Correlation activity}

Based on the results of phytochemical screening showed that the $C$. racemosa extract was positive contained tannins, flavonoids and steroids. Several studies have reported that tannin and flavonoid compounds have an aromatic ring in the form of chromophore which can absorb UV rays. When UV light interacts with aromatic compounds or compounds containing conjugated chromophore there will be resonance by electron transfer (Choquenet et al., 2008; Cefali et al., 2016; Nunes et al., 2018). In this study, the results obtained that the amount of antioxidant activity has a positive correlation with the protective effect against UV rays (sunscreen) which can be seen in Figure 4. Figure 4 indicates that the antioxidant activity of the three types of seaweed gives a correlation of $73.2 \%$ to the activity as UV Protection. This very supportive of skin repair when there is excessive exposure to UV light so that the content of compounds contained in seaweed can be developed as a medical cosmetics' raw material.

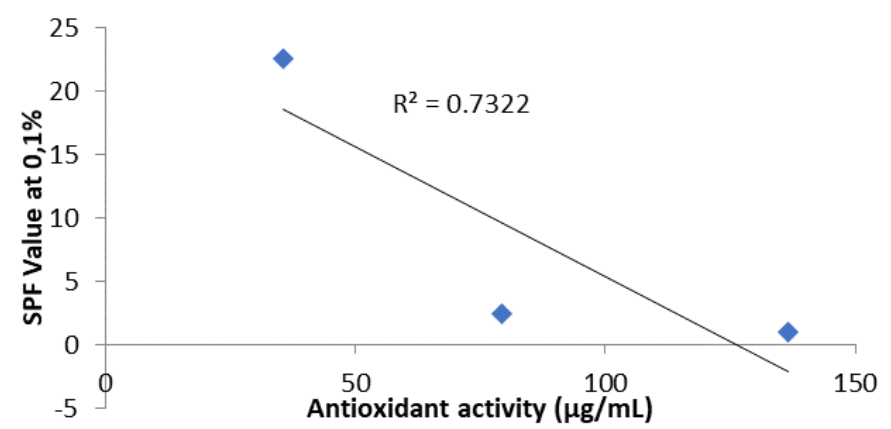

Figure 4. Correlation between SPF value against antioxidant activity of three types of seaweeds

\section{Conclusion}

The three types of seaweed i.e. E. cottoni, $S$. polycystum and C. racemosa, provide bioactivity against antioxidant activity and protective effects against UV exposure so that it has a perspective to be developed.

\section{Conflict of interest}

The authors declare no conflict of interest.

\section{Acknowledgments}

On this occasion, we would like to thank for the Indonesian Ministry of Education for the research funding of doctoral dissertations.

\section{References}

Adhita Putera, B. (2015). Aktivitas Antioksidan Rumput Laut Caulerpa sp. Segar dan Rebus. Indonesia: Institut Pertanian Bogor, BSc. Thesis. [In Bahasa Indonesia].
Alam Bhuiyan, M.K. and Qureshi, S. (2016). Proximate Chemical Composition of Sea Grapes Caulerpa racemosa (J. Agardh, 1873) Collected from a SubTropical Coast. Virology and Mycology, 5(2), 1-6. https://doi.org/10.4172/2161-0517.1000158

Apak, R., Güçlü, K., Demirata, B., Özyürek, M., Çelik, S.E., Bektaşoğlu, B., Berker, K.I. and Özyurt, D. (2007). Comparative evaluation of various total antioxidant capacity assays applied to phenolic compounds with the CUPRAC assay. Molecules, 12 (7), 1496-1547. https://doi.org/10.3390/12071496

Arsianti, A., Aziza, Y.A.N., Kurniasari, K.D., Mandasari, B.K.D., Masita, R., Zulfa, F.R., Dewi, M.K., Zagloel, C.R.Z., Azizah, N.N. and Putrianingsih, R. (2018). Phytochemical test and cytotoxic activity of macroalgae Eucheuma cottonii against cervical HeLa cells. Pharmacognosy Journal, 10(5), 1012-1017. https://doi.org/10.5530/ pj.2018.5.172

Balsam, M.S. and Sagarin, E. (1972). Cosmetics: Science and Technology, New York: WileyInterscience.

Bitencourt, M.A.O., Silva, H.M.D., Abílio, G.M.F., Miranda, G.E.C., Moura, A.M.A., de Araújo-Júnior, J.X., Silveira, E.J.D., Santos, B.V.O. and Souto, J.T. (2015). Anti-inflammatory effects of methanolic extract of green algae Caulerpa mexicana in a murine model of ulcerative colitis. Brazilian Journal of Pharmacognosy, 13(5), 603-608. https:// doi.org/10.1016/j.bjp.2015.10.001

Cahyaningrum, K., Husni, A., Budhiyanti, S.A. and Perikanan, J. (2016). Aktivitas Antioksidan Ekstrak Rumput Laut Cokelat. Agritech, 36(2), 1-8. https:// doi.org/10.22146/agritech.12857

Cefali, L.C., Ataide, J.A., Moriel, P., Foglio, M.A. and Mazzola, P.G. (2016). Plant-based active photoprotectants for sunscreens. International Journal of Cosmetic Science, 38(1), 346-353. https:// doi.org/10.1111/ics.12316

Chan, Y.S., Ong, C.W., Chuah, B.L., Khoo, K.S., Chye, F.Y. and Sit, N.W. (2018). Antimicrobial, antiviral and cytotoxic activities of selected marine organisms collected from the coastal areas of Malaysia. Journal of Marine Science and Technology (Taiwan), 26(1), 128-136. https://doi.org/10.6119/JMST.2018.02_ (1). 0012

Chandini, S.K., Ganesan, P. and Bhaskar, N. (2008). In vitro antioxidant activities of three selected brown seaweeds of India. Food Chemistry, 107(2), 707713. https://doi.org/10.1016/j.foodchem.2007.08.081

Choquenet, B., Couteau, C., Paparis, E. and Coiffard, L.J.M. (2008). Quercetin and rutin as potential 
sunscreen agents: Determination of efficacy by an in vitro method. Journal of Natural Products, 71(6), 1117-1118. https://doi.org/10.1021/np7007297

Donglikar, M.M. and Deore, S.L. (2016). Sunscreens: A review. Pharmacognosy Journal, 8(3), 171-179. https://doi.org/10.5530/pj.2016.3.1

Eff, A.R.Y., Pertiwi, R.D., Rakhmawati, I. and Utami, T.P. (2018). In-vitro and in-vivo sunscreen activity of active compounds isolated from fruits of Phaleria marcocarpha (Scheff.) boerl. Journal of Young Pharmacists, 10(2), 106-110. https:// doi.org/10.5530/jyp.2018.2s.21

Harborne, J.B. (1998). Phytochemical Methods A Guide To Modern Techniques of Plant Analysis. 3rd ed. The Netherlands: Springer.

Hong, D.D., Hien, H.M. and Anh, H.T.L. (2011). Studies on the analgesic and anti-inflammatory activities of Sargassum swartzii (Turner) C. agardh (Phaeophyta) and Ulva reticulata Forsskal (Chlorophyta) in experiment animal models. African Journal of Biotechnology, 10(2), 2308-2314. https:// doi.org/10.5897/AJB10.213

Subrathraa, K. and Poonguzhali, T.V. (2013). Effect of different extracts of Chaetomorpha antennina and their phytochemical screening. International Journal of Current Science, 6(1), 35-39.

Kania, N., Mayangsari, E., Setiawan, B., Nugrahenny, D., Tony, F., Wahyuni, E.S. and Widodo, M.A. (2013). The effects of Eucheuma cottonii on signaling pathway inducing mucin synthesis in rat lungs chronically exposed to particulate matter 10 (PM 10) coal dust. Journal of Toxicology, 2013, 528146. https://doi.org/10.1155/2013/528146

Kılınç, B., Cirik, S. and Turan, G. (2013). Seaweeds for Food and Industrial Applications. In Muzzalupo, I. (Ed.) Food Industry. InTech Open E-Book. https:// doi.org/10.5772/47766.

Kraan, S. (2012). Algal Polysaccharides, Novel Applications and Outlook. In Chang, F.-C. (Ed.) Carbohydrates - Comprehensive Studies on Glycobiology and Glycotechnology. InTech Open EBook. https://doi.org/10.5772/51572

Kumar, M., Gupta, V., Kumari, P., Reddy, C.R.K. and Jha, B. (2011). Assessment of nutrient composition and antioxidant potential of Caulerpaceae seaweeds. Journal of Food Composition and Analysis, 30(1), 937-954. https://doi.org/10.1016/j.jfca.2010.07.007

MacArtain, P., Gill, C.I.R., Brooks, M., Campbell, R. and Rowland, I.R. (2008). Nutritional Value of Edible Seaweeds. Nutrition Reviews, 65(12) 535543. https://doi.org/10.1111/j.17534887.2007.tb00278.x
Matanjun, P., Mohamed, S., Mustapha, N.M., Muhammad, K. and Ming, C.H. (2008). Antioxidant activities and phenolics content of eight species of seaweeds from north Borneo. Journal of Applied Phycology, 20(4) 367-373. https://doi.org/10.1007/ s10811-007-9264-6

Mistriyani, Riyanto, S. and Rohman, A. (2018). Antioxidant activities of rambutan (Nephelium lappaceum L) peel in vitro. Food Research, 2(1) 119 -123. https://doi.org/10.26656/fr.2017.2(1).150

Muawanah, Ahmad, A. and Natsir, H. (2016). Antioxidant activity and toxicity polysaccharide extract from red algae Eucheuma spinosum and Eucheuma cottonii. Marina Chimica Acta, 17(2) 1-8.

Nofiani, R., Hertanto, S., Zaharah, T.A. and Gafur, S. (2018). Proximate Compositions and Biological Activities of Caulerpa lentillifera. Molekul, 1(3) 141147. https://doi.org/10.20884/1.jm.2018.13.2.441

Nunes, A.R., Vieira, Í.G.P., Queiroz, D.B., Leal, A.L.A.B., Maia Morais, S., Muniz, D.F., CalixtoJunior, J.T. and Coutinho, H.D.M. (2018). Use of Flavonoids and Cinnamates, the Main Photoprotectors with Natural Origin. Advances in Pharmacological Sciences, 2018, 5341487. https:// doi.org/10.1155/2018/5341487

Nur, S., Mubarak, F., Jannah, C., Winarni, D.A., Rahman, D.A., Hamdayani, L.A. and Sami, F.J. (2019). Total phenolic and flavonoid compounds, antioxidant and toxicity profile of extract and fractions of paku atai tuber (Angiopteris ferox Copel). Food Research, 3(6) 734-740. https:// doi.org/10.26656/fr.2017.3(6).135

Pakki, E., Murdifin, M., Wijoyo, N. and Sumarheni, S. (2018). Study of sunscreen and antioxidant activity of combination extracts from the red algae Eucheuma cottonii and Eucheuma spinosum. Drug Invention Today, 10(9) 1827-1830.

Sami, F.J., Soekamto, N.H., Firdaus, F. and Latip, J. (2019). Uji Aktivitas Antioksidan Beberapa Ekstrak Alga Coklat Sargassum Polycystum Dan Turbinaria Deccurens Asal Pulau Dutungan Sulawesi Selatan Terhadap Radikal DPPH. Jurnal Kimia Riset, 4(1) 16. [In Bahasa Indoensia]. https://doi.org/10.20473/ jkr.v4i1.10903

Sinurat, E. and Fadjriah, S. (2019). The Chemical Properties of Seaweed Caulerpa lentifera from Takalar, South Sulawesi. IOP Conference Series: Materials Science and Engineering, 546(1) 1-6. https://doi.org/10.1088/1757-899X/546/4/042043

Suryaningrum, T.D., Wikanta, T. and Kristiana, H. (2006). Uji Aktivitas Senyawa Antioksidan dari Rumput Laut Halymenia harveyana dan Eucheuma 
cottonii. Jurnal Pascapanen dan Bioteknologi Kelautan Dan Perikanan, 1(1) 51-64. https:// doi.org/10.15578/jpbkp.v1i1.231. [In Bahasa Indonesia].

Tanna, B. and Mishra, A. (2019). Nutraceutical Potential of Seaweed Polysaccharides: Structure, Bioactivity, Safety, and Toxicity. Comprehensive Reviews in Food Science and Food Safety, 18(3) 817-831. https://doi.org/10.1111/1541-4337.12441

Wresdiyati, T., Hartanta, A. B. and Astawan, M.A.D.E. (2008). The Effect of Seaweed Eucheuma cottonii on Superoxide Dismutase (SOD) Liver of Hypercholesterolemic Rats. HAYATI Journal of Biosciences, 15(3) 105-110. https://doi.org/10.4308/ hjb.15.3.105

Yanuarti, R., Nurjanah, N., Anwar, E. and Hidayat, T. (2017). Profil fenolik dan aktivitas antioksidan dari ekstrak rumput laut Turbinaria conoides dan Eucheuma cottonii. Jurnal Pengolahan Hasil Perikanan Indonesia, 20(2) 230-237. [In Bahasa Indoensia].

Yap, W.F., Tay, V., Tan, S.H., Yow, Y.Y. and Chew, J. (2019). Decoding antioxidant and antibacterial potentials of Malaysian green seaweeds: Caulerpa racemosa and Caulerpa lentillifera. Antibiotics, 8(3) 1-18. https://doi.org/10.3390/antibiotics8030152

Yende, S., Harle, U. and Chaugule, B. (2014). Therapeutic potential and health benefits of Sargassumspecies. Pharmacognosy Reviews, 8(15) 1 -7. https://doi.org/10.4103/0973-7847.125514 